\title{
Retail prices of essential drugs in Brazil: an international comparison
}

\author{
Otávio de Tolêdo Nóbrega, ${ }^{1}$ André Ricardo Marques, ${ }^{2}$ \\ Ana Cleire Gomes de Araújo, ${ }^{2}$ Margô Gomes de Oliveira Karnikowski, ${ }^{1}$ \\ Janeth de Oliveira Silva Naves, ${ }^{2}$ and Lynn Dee Silver ${ }^{2}$
}

Suggested citation Nóbrega OT, Marques AR, Araújo ACG, Karnikowski MGO, Naves JOS, Silver LD. Retail prices of essential drugs in Brazil: an international comparision. Rev Panam Salud Publica. 2007;22(2):118-23.

ABSTRACT Objectives. Price is a key obstacle for consumer access to essential drugs, especially in developing countries. This study sought to compare the retail prices of essential drugs on the private market in Brazil with that of two international pricing standards.

Methods. The retail price of all drugs on Brazil's Essential Drugs List, July 2000 edition, were compared to the retail price of the same drugs on the Swedish market and on a referential bulk-price indicator from low-cost suppliers on the international market. Ratios of Brazil's prices to Sweden's prices and Brazil's prices to the international bulk mean price-per-unit for each drug were calculated. Using linear regression analysis, the ratios were also studied in relation to the number of manufacturers.

Results. For the 132 drugs that were listed on both Brazil's and Sweden's lists, unitary retail prices in Brazil were 1.9 times higher. Of the 94 drugs found on both Brazil's list and the international unit-price indicator, Brazil's national mean unit prices were 13.1 more expensive. No relationship was found between the number of manufacturers for each product and the ratios of prices.

Conclusions. Average retail prices of essential drugs in Brazil are significantly higher than in Sweden. Furthermore, international bulk prices indicate that drugs are brought to market by Brazil's private pharmacies at prices that may be excessively high in relation to production costs, creating high profit margins. The expected price-lowering effects of competition were not identified.

Key words Drugs, essential; drug costs; economics, pharmaceutical; health policy; Brazil.

Effective health systems must provide more than health prevention and

1 Curso de Farmácia and Programa de PósGraduação em Gerontologia, Universidade Católica de Brasília, Brasilia, Brazil. Send correspondence to: Otávio de Tolêdo Nóbrega, Programa de Pós-Graduação em Gerontologia, Universidade Católica de Brasília, EPCT Q.S. 7, lote 1-Águas Claras, Brasília-DF, CEP 72030-170. Brazil; telephone: (5561) 3356 9693; fax: (5561) 3356 3010; e-mail: nobrega@ucb.br.

2 Curso de Ciências Farmacêuticas, Faculdade de Ciências da Saúde, Universidade de Brasília, Brasilia, Brazil. promotion activities; they must guarantee access to quality services and goods, especially essential drugs. Price is clearly the single, greatest barrier to the population's access to essential drugs (1-3). Yet, in most poor countries, insufficient spending and limited regulation of public health make access to drugs a difficult challenge.

While Brazil's national drug policy (4) calls for distribution of essential drugs through the universal public health system, the stocking of these drugs in outpatient facilities is still deficient. A previous study by the authors revealed an average availability of only $50 \%$ of items intended for distribution (5). This, and other works (6, 7 ), show that essential drugs are only moderately available, almost 30 years after the first Brazilian essential drugs list was created. This means that most families must obtain basic pharma- 
cotherapy through one of Brazil's approximately 50000 private pharmacies.

In the wave of deregulation that swept Latin America in the late 1980s and early 1990s, Brazil largely deregulated pharmaceutical prices in 1992. Before that, drug prices were strictly regulated by the Comitê Interministerial de Preços (CIP), an interministry council charged with monitoring prices of several goods, including medicine and other health-related products. In addition, the Central de Medicamentos (CEME), a national pharmaceuticals agency within the Ministry of Health, was responsible for essentialdrug supply policy and greatly contributed to stabilizing retail prices (8). Since 1992, when CIP and CEME were deactivated, prices were to be formally monitored by the government, a task assigned initially to an executive committee for economic protection, the Conselho Administrativo de Defesa Econômica (CADE), within the Ministry of Justice (1994-1996); and later, to a secretariat for economic surveillance, the Secretaria de Acompanhamento Econômico, (SEAE) within the Ministry of Finance (1997-1999) (9).

None of these strategies restrained an unprecedented ramping-up of drug prices throughout the 1990s. Overall earnings of pharmaceutical companies in Brazil grew rapidly-from US\$ 3 billion annually, in the late 1980s, to nearly US\$ 10 billion in 1998-while the actual units of drugs sold remained relatively the same (10). Private manufacturers, the major drug providers, began to set retail prices that were marked-up to cover wholesale and retail activities, as well as tax liability.

The combination of poor distribution of essential drugs by the public sector and weak legislation on drug pricing adversely affect accessibility and burden consumers with added expenses. In 2000, some regulatory mechanisms were reestablished to allow or disallow percentage increases in prices due to changing inflation rate, exchange rates, and raw material costs. In addition, a few limitations were set on retail mark-ups and some tax exemptions were created. However, none of the price adjustment measures implemented since 2000 have taken into account standards of acceptable profit margins, international pricing comparisons, or affordability studies. Also, although Brazil introduced a generic drug policy in 1999-2000 (11), very few of the products now registered under the new law were available on the market then.

At this time, the prices paid by the consumer included a pharmacy markup as high as $30 \%$ of a medication's total price. Moreover, a federal tax of $6 \%$ and a state tax of $17-18 \%$ were imposed (12). Data presented to a Parliamentary Commission of Inquiry in Brazil revealed that as little as $20 \%$ of the wholesale price was actually related to production costs (13). In 2002, the retail pharmacy market in Brazil plunged back to US\$ 3.8 billion due to a devaluation of the Brazilian currency (14), but prices in local currency continued to rise.

Systematic comparisons of drug pricing are lacking; therefore, data needed to guide national drug pricing policies, in Brazil and elsewhere, are insufficient. An Australian study found ratios as high as 3.5 to 1 for manufacturer list-prices of the most widely-used drugs in the United States of America (USA) as opposed to Australia (15). In 1993, Abbas and Bermudez (16) pointed out the need for more systematic evaluations and international comparisons in Brazil, but subsequent work has been lacking (17). Additional international studies are particularly important to health policy development in middle- and lowerincome countries where average percapita income can be up to 30 times lower than in the most affluent nations. In addition, there are indications that drug prices are sometimes higher in poorer countries (1).

Thus, to guide policy making for improved access to essential drugs, this study was undertaken to clarify whether retail prices of essential drugs in Brazil are "high" or "low" in relation to two standards of comparison: retail prices in Sweden and bulk international prices from low-cost suppliers on the international market.

\section{METHODS}

For all essential drugs, either brand name or otherwise labeled products, whose active ingredient(s) and pharmaceutical preparations were on Brazil's National List of Essential Drugs (Relação Nacional de Medicamentos Essenciais, RENAME), July 2000 edition, the unit price was calculated based on two monthly, drug-price guides-the ABCFarma, June-July 2000 (18), and DMG, July 2000 (19). Since both are independent publications, but ABCFarma was more comprehensive, it was adopted as the standard list, while $D M G$ was referred to solely if a price was missing from ABCFarma. Unit prices were calculated independently for each dosage form of a given drug.

Each tablet, milliliter of solution, gram of ointment, or dose of aerosols was considered a "unit." If more than one manufacturer offered the same product, an arithmetic mean unit-price was calculated from all the drugs with the same active ingredient(s) in the same form. Consumption-weighted means were not used due to the unavailability of adequate sales information for each brand.

For each drug, prices for comparison were sought from two international sources. The first source was the International Drug Price Indicator Guide (IDPIG), a publication produced by Management Sciences for Health (20), with support from various international organizations and agencies. IDPIG provides referential pricing for drugs on the international market. Prices, listed in U.S. dollars (USD), were converted to Brazilian currency using the mean exchange rate for July 2000 (1 USD = 1.797 Brazilian Real). Note that these prices are for drugs supplied in bulk, and do not reflect the cost of consumer packaging or distribution. Since the pharmacoeconomics literature lacks estimates on what percentage of retail prices in Brazil are attributable to actual production costs, prices for drugs supplied in bulk were used as an approximation of the production costs-based on the assumption they carry relatively-low profit margins, but are not sold at a loss. 
The second comparison drew from retail pharmacy prices offered by Sweden's National Corporation of Pharmacies (Apoteket AB), a publicly-owned, non-profit corporation that administers all the country's pharmacies. In 1999, Apoteket AB carried out a study of the growing price of a basket of drugs in 15 European countries, showing a gradual convergence of prices, with Sweden as one of the countries with slightly lower, but not the lowest, prices in the region (21). Swedish prices were converted to Brazilian currency, taking into account the average exchange rate for July 2000 ( 1 SEK $=0.1862$ Brazilian Real). The resulting retail price was used as a standard to represent the sum result of economic determinants that affect pharmaceutical pricing (e.g., manufacturers' costs and profits, taxation, wholesale and retail costs, and profit margins), and ultimately consumer access, in a given developed country. Even though the Apoteket AB list reflected prices from 1999, comparisons in 2000 reflected the assumption that price alteration of particular products in the course of one year would not substantially influence mean unit prices. This assumption was confirmed soon after completion of the analysis-10 randomly-selected dosage forms were compared and had not changed in terms of mean unitprices from 1999 and 2000.

To evaluate the hypothesis that competition would keep pricing in check, ratios of Brazil's mean unit-prices to IDPIG prices and to Swedish prices were calculated taking into account the number of manufacturers offering the product on the Brazilian market. Linear and logarithmic regression models were employed using the price ratios as the dependent variable and the number of manufacturers as the independent variable. All analyses were performed employing the Statistical Package for Social Sciences (SPSS), version 10.0, for Windows (SPSS Inc., Chicago, Illinois, USA).

\section{RESULTS}

In 2000, RENAME listed 282 pharmaceutical products. Of these, a group of 83 items, primarily hospital-use drugs, vaccines, and medical devices, did not appear on the price lists for the Brazil's retail pharmacy market, and therefore, were excluded from the study. Of the remaining 199 items, only 94 drugs (120 dosage forms) could be priced on the IDPIG database. On the Swedish database, drugs were matched according to the Anatomical-Therapeutic-Chemical (ATC) Classification System, and it was possible to analyze 132 drugs (200 dosage forms). These discrepancies occurred because of several drugs that are no longer being produced and sold by other countries (e.g., dipyrone), but are still available in Brazil.

\section{Comparisons with Sweden's retail prices}

Comparisons between retail drug prices in Sweden and Brazil showed that overall prices in Brazil were 1.9 times higher than in Sweden, but $45 \%$ of the 132 drugs cost less in Brazil. The most notable discrepancy in the Brazil/Sweden ratio was cyclophosphamide (200 mg injectable solution), which was found to be 13 times more expensive in Brazil. Similarly, medroxyprogesterone (5 mg tablets) was 9.2 times more expensive in Brazil; paracetamol (200 mg/mL oral solution), 8.9 times more; and cephazoline (1 $\mathrm{g}$ ampoules) 6.5 times more (Table 1). On the other hand, allopurinol (100 mg tablet) was 9.1 times less expensive in Brazil; amoxicillin (250 mg powder), 3.2 times less; and ethambutol (400 mg tablet), 7.8 times less.

\section{Comparison with international bulk prices}

Of the 94 drugs-120 total dosage forms-that were compared, only 3\% had a retail price in Brazil that was lower than the mean bulk price. This is not surprising given that the comparison was between retail and bulk prices. Although there are no standard guidelines available for comparing the two, the retail price of some products in
TABLE 1. The 20 essential drugs (and dosage forms), of the 200 compared, with the highest ratios between retail prices ${ }^{a}$ in Brazil and Sweden, 2000

\begin{tabular}{lc}
\hline \multicolumn{1}{c}{ Drug } & Price ratio \\
\hline Morphine, tablet $10 \mathrm{mg}$ & 2.8 \\
Aciclovir, tablet $200 \mathrm{mg}$ & 2.8 \\
Metformin cloridrate, tablet & \\
$500 \mathrm{mg} / 850 \mathrm{mg}$ & 2.8 \\
Levothyroxine, tablet $50 \mathrm{\mu g}$ & 2.9 \\
Methyldopa, tablet $250 \mathrm{mg}$ & 2.9 \\
Methotrexate, tablet $2.5 \mathrm{mg}$ & 3.0 \\
Furosemide, injectable solution & \\
$\quad 10 \mathrm{mg} / \mathrm{mL}$ & 3.2 \\
Nortryptiline, tablet $10 \mathrm{mg}$ & 3.6 \\
Cisplatinum, injectable solution $25 \mathrm{mg}$ & 3.7 \\
Amphotericin B, injectable solution & \\
$\quad 50 \mathrm{mg}$ & 3.8 \\
Isoflurane, inhalation fluid & 4.2 \\
Tamoxifen, tablet $20 \mathrm{mg}$ & 4.2 \\
Streptokinase, injectable solution & \\
$\quad 250,000$ Ul & 4.5 \\
Metronizadol, vaginal cream $5 \%$ & 4.9 \\
Paracetamol, tablet $500 \mathrm{mg}$ & 5.4 \\
Dopamine, injectable solution $5 \mathrm{mg}$ & 5.9 \\
Cephazolin, ampoule $1 \mathrm{~g}$ & 6.5 \\
Paracetamol, oral solution $200 \mathrm{mg} / \mathrm{mL}$ & 8.9 \\
Medroxyprogesterone, tablet $5 \mathrm{mg}$ & 9.2 \\
Cyclophosphamide, injectable solution & \\
200 mg & 13.4 \\
\hline
\end{tabular}

a Sources: ABCFarma (18); DMG (19); Apoteket price list (21).

Brazil seemed excessively high relative to the international bulk price. Of the 120 comparable product types, 56 displayed ratios above 10. Among the greatest retail/bulk ratios were bupivacaine $(0.5 \mathrm{mg} / \mathrm{mL})$, which was 78 times more expensive in Brazil; aminophylline ( $24 \mathrm{mg} / \mathrm{mL}$ ampoules), 54.3 times more; and haloperidol (5 $\mathrm{mg}$ tablets), 51 times more. The mean retail unit-price of these 94 essential drugs was 13.1 times greater than the mean bulk unit-price of the same drugs cited by the IDPIG source. The 50 drugs with the highest ratios appear in Table 2. Even widely-used drugs with multiple manufacturers, such as paracetamol and mebendazol, had retail prices over 50 times the international bulk price.

\section{Effects of competition}

To understand the effect of competition on drug pricing, the relationship between the price ratios and the num- 
TABLE 2. The 40 essential drugs (and dosage forms) of the 120 compared, with the highest ratios between mean unit prices ${ }^{\mathrm{a}}$ on the retail market in Brazil and in bulk on the international market; and the number of manufacturers per drug in Brazil, 2000

\begin{tabular}{|c|c|c|}
\hline Drug & Price ratio & $\begin{array}{c}\text { No. of } \\
\text { manufacturers in Brazil }\end{array}$ \\
\hline Methyldopa, tablet $250 \mathrm{mg}$ & 12.3 & 17 \\
\hline Phenbarbital, injectable solution $100 \mathrm{mg} / \mathrm{mL}$ & 12.7 & 4 \\
\hline Benzathine benzylpenicillin, powder $600,000 \mathrm{UI}$ & 15.2 & 7 \\
\hline Benzyl benzoate, emulsion $250 \mathrm{mg} / \mathrm{mL}$ & 15.4 & 7 \\
\hline Acetylsalicylic acid, tablet $500 \mathrm{mg}$ & 15.5 & 20 \\
\hline Nitrofurantoin, oral suspension $5 \mathrm{mg} / \mathrm{mL}$ & 15.7 & 2 \\
\hline Lidocaine, ointment 20 mg/g & 15.7 & 3 \\
\hline Calcium gluconate, injectable solution $100 \mathrm{mg} / \mathrm{mL}$ & 16.0 & 1 \\
\hline Hydrochlorthiazide, tablet $25 \mathrm{mg}$ & 16.1 & 2 \\
\hline Ampicillin, powder $1 \mathrm{~g}$ & 16.6 & 11 \\
\hline Prednisone, tablet $20 \mathrm{mg}$ & 17.0 & 9 \\
\hline Gentamycin, injectable solution $10 \mathrm{mg} / \mathrm{mL}$ & 17.5 & 12 \\
\hline Promethazine, tablet $25 \mathrm{mg}$ & 17.8 & 4 \\
\hline Glibenclamide, tablet $5 \mathrm{mg}$ & 18.5 & 10 \\
\hline Digoxin, tablet $0.25 \mathrm{mg}$ & 18.8 & 9 \\
\hline Ibuprofen, tablet $300 \mathrm{mg}$ & 19.0 & 4 \\
\hline Dexamethasone, tablet $0.5 \mathrm{mg}$ & 20.3 & 10 \\
\hline Salbutamol, syrup $2 \mathrm{mg} / 5 \mathrm{~mL}$ & 20.3 & 26 \\
\hline Sodium heparin, injectable solution $5000 \mathrm{UI} / \mathrm{mL}$ & 20.5 & 2 \\
\hline Amoxicillin, oral suspension $250 \mathrm{mg} / 5 \mathrm{~mL}$ & 21.2 & 28 \\
\hline Diazepam, tablet $2 \mathrm{mg}$ & 21.8 & 14 \\
\hline Levothyroxine, tablet $100 \mu \mathrm{g}$ & 23.3 & 4 \\
\hline Salbutamol, aerosol $100 \mu \mathrm{g} / \mathrm{dose}$ & 23.7 & 10 \\
\hline Dexamethasone, injectable solution $4 \mathrm{mg} / \mathrm{mL}$ & 24.4 & 8 \\
\hline Furosemide, injectable solution $10 \mathrm{mg} / \mathrm{mL}$ & 24.9 & 11 \\
\hline Nifedipine, tablet $20 \mathrm{mg}$ & 25.0 & 8 \\
\hline Metoclopramide, tablet $10 \mathrm{mg}$ & 25.1 & 13 \\
\hline Metronizadol, vaginal cream $5 \%$ & 29.8 & 24 \\
\hline Loperamide, tablet $2 \mathrm{mg}$ & 34.1 & 3 \\
\hline Amytriptiline, tablet $25 \mathrm{mg}$ & 34.9 & 6 \\
\hline Ergometrine, tablet $200 \mu \mathrm{g}$ & 36.0 & 3 \\
\hline Doxycycline, tablet $100 \mathrm{mg}$ & 36.2 & 3 \\
\hline Folic acid, tablet $5 \mathrm{mg}$ & 36.7 & 5 \\
\hline NPH human insulin, injectable solution $100 \mathrm{UI} / \mathrm{mL}$ & 36.7 & 3 \\
\hline Albendazol, tablet $400 \mathrm{mg}$ & 47.5 & 7 \\
\hline Paracetamol, tablet $500 \mathrm{mg}$ & 51.0 & 22 \\
\hline Haloperidol, tablet $5 \mathrm{mg}$ & 51.0 & 3 \\
\hline Mebendazol, oral suspension $100 \mathrm{mg} / 5 \mathrm{~mL}$ & 51.3 & 46 \\
\hline Aminophylline, ampoule 24 mg/mL & 54.3 & 6 \\
\hline Bupivacaine $0.5 \mathrm{mg} / \mathrm{mL}$ & 78.1 & 1 \\
\hline
\end{tabular}

a Sources: ABCFarma (18); DMG (19); IDPIG database (20).

ber of manufacturers for each drug on the Brazilian market was examined using analyzed by mathematical regression. Linear $\left(R^{2}=0.04\right)$ and logarithmic $\left(R^{2}=0.16\right)$ models could not detect a significant relationship.

\section{DISCUSSION AND CONCLUSIONS}

The relatively simple method employed in this study compares the re- tail unit-price of essential drugs on the commercial market in Brazil to the unit-price of the same products in a developed country (Sweden) and available in large quantities on the international market. The data suggest that these drugs reach Brazilian consumers at prices many times above the cost of production and the price at which they are sold in other settings. Obviously, shipping, packaging, and distribution costs, as well as taxation, contribute to the final, retail price of a drug. However, these routine expenses over-and-above production are unlikely to explain a 13-fold increase over the IDPIG mean prices. Price composition data supplied by pharmaceutical companies to Brazil's Parliament suggest that the cost of production typically comprises $42.6 \%$ of the retail price (13). Brazilian regulation permitted pharmacies to mark-up the pharmaceutical manufacturer's set price by $30 \%$ over production costs, at the time of this study; in addition, the sales tax, accounted for another $10.3 \%$ increase (22). Regardless, neither of these fully accounts for the marked difference between Brazil's prices and those of the two other markets. Likewise, it may be that production costs in Brazil are higher than those of suppliers to the IDGIP-monitored buyers, but it is unlikely that the difference accounts for the final findings. Furthermore, the comparison with retail prices in Sweden suggests that when a system couples price negotiations with public interest goals, it maintains lower profit-margins for both distribution and retail activities.

The Productivity Commission study on international drug prices, carried out in Australia almost simultaneously to this work, found that manufacturers' prices for a given basket of 150 drugs was nearly $50 \%$ more in Sweden and $200 \%-300 \%$ higher, on average, in the USA, than in Australia (15). Since our study looked at consumer prices in Brazil, the data from Australia suggest that prices in Sweden represent a midpoint between countries with the more rigorous economic controls, such as Australia and New Zealand, and those with fewest pricing regulations, such as the USA. Therefore, the fact that retail prices for essential drugs in Brazil are almost twice that of the same medications in Sweden, and taking into account that Brazil's average income level is 10 times lower, high prices must restrict access to essential drugs for lowincome Brazilians.

Another conclusion is that competition alone is not enough to guarantee affordable pricing of essential drugs in Brazil. In fact, governmental state- 
ments themselves have acknowledged that competition on its own does not prevent abusive drug pricing (23). In addition, voluntary differential pricing of essential pharmaceuticals for middle- and low-income countries does not appear to be occurring in Brazil. The high ratio between privateretail and international-bulk price data suggests that the public-interest procurement and distribution systems called for by the Brazil's Health Policy, although only partially implemented (24), may offer the most cost-effective method for guaranteeing access to essential drugs.

All in all, the relatively simple method described in this work may be useful for drawing comparison between countries and arriving at some international standard. In addition, comparing retail prices to number of manufacturers may afford a method for assessing whether the market is functioning freely or whether other price-establishing mechanisms are at play. In Brazil, the results of this study point to the need for effectively regulating pharmaceutical pricing so that a balance is achieved between the cost of production, wholesale, and the retail price of essential drugs.

Acknowledgements. Thanks to Apoteket AB for supplying its official price list, and specifically, to Orjan Akerren of Apotekt $A B$ for providing supporting data. For financial support of the research and action partnership between the University of Brasilia and
IDEC on access to essential drugs, we thank the John D. and Catherine T. MacArthur Foundation (USA); Oxfam UK (United Kingdom); and The Rockefeller Foundation (USA) The authors are also greatly indebted to Dr. Anthony Robbins and Dr. Phyllis Freeman, Northeastern University School of Law, for their careful review of the manuscript.

Declaration of potential conflicts of interest: Otávio de Tolêdo Nóbrega, Lynn Dee Silver, and Margô Gomes de Oliveira Karnikowski have received support from the Institute for Consumer Protection, Brazil; and Janeth de Oliveira Silva Naves has received support from the Ministry of Justice, Brazil, for work on drug price issues.

\section{REFERENCES}

1. Henry D, Lexchin J. The pharmaceutical industry as a medicines provider. Lancet 2002; 360(9345):1590-5.

2. Steinbrook R. The prescription-drug problem. N Engl J Med 2002;346(11):790.

3. Pecoul B, Chirac P, Troullier P, Pinel J. Access to essential drugs in poor countries: a lost battle? JAMA 1999;281(4):361-7.

4. Brasil, Ministério da Saúde. Portaria n 3.916 (Política Nacional de Medicamentos). Diário Oficial da União. Brasília: Imprensa Nacional; 10 novembro 1998.

5. Karnikowski MG, Nóbrega OT, Naves JO, Silver LD. Access to essential drugs in 11 Brazilian cities: a community-based evaluation and action method. J Public Health Policy 2004; 25(3-4):288-98.

6. Naves JOS, Silver LD. Evaluation of pharmaceutical assistance in public primary care in Brasília, Brazil. Rev Saúde Pública 2005;39(2): 223-30.

7. Guerra Jr AA, Acúrcio F de A, Gomes CAP, Miralles M, Girardi SN, Werneck GAF, et al. Disponibilidade de medicamentos essenciais em duas regiões de Minas Gerais, Brasil. Rev Panam Salud Publica 2004;15(3):168-75.

8. Bermudez JAZ. Remédios: Saúde ou Indústria? A produção de medicamentos no Brasil. Rio de Janeiro: Relume Dumará; 1992.

9. Bermudez JAZ. Indústria farmacêutica: estado e sociedade. São Paulo: Hucitec/Abrasco; 1995.
10. Sindicato da Indústria de Produtos Farmacêuticos do Estado de São Paulo. Indicadores [Internet site]. Available from: http://www. sindusfarma.org.br. Accessed 10 June 2001.

11. Brasil. Lei $n^{\circ} 9.787$ (Lei dos Medicamentos Genéricos). Diário Oficial da União. Brasília: Imprensa Nacional; 11 fevereiro 1999.

12. Cohen JC. Public policies in the pharmaceutical sector: a case study of Brazil. Washington, DC: World Bank; 2000

13. Comissão Parlamentar de Inquérito. Relatório final da CPI dos medicamentos. Brasília: Câmara dos Deputados; 2000.

14. Machado-dos-Santos SC. Melhoria da equidade no acesso aos medicamentos no Brasil: os desafios impostos pela dinâmica da competição extra-preço. [Masters dissertation]. Rio de Janeiro: Fundação Oswaldo Cruz, Escola Nacional de Saúde Pública; 2001. 180 pp.

15. Productivity Commission. International pharmaceutical price differences. [AusInfo research report]. Canberra, Australia: 2001.

16. Abbas R, Bermudez J. Preços no Brasil superam em muito os do mercado internacional. Tema/Radis 1993;13:10-2.

17. Bermudez J, Almeida dos Reis AL. A necessidade de se comparar preços nos mercados farmacêuticos. In: Bermudez J, Bonfim J. eds. Medicamentos e a Reforma do Setor Saúde. São Paulo: Hucitec/Sobravime; 1999. 179-91 pp.
18. Associação Brasileira do Comércio Farmacêutico (ABCF). Rev ABCFarma. 109 ed. São Paulo: Febrafarma; 2000.

19. Instituto Brasileiro de Defesa dos Usuários de Medicamentos (IDUM). Revista DMG 2000 18 ed. Brasília: IDUM, 2000.

20. Management Sciences for Health. International drug price indicator guide (IDPIG). Boston: MSH; 1999.

21. Apoteket Agency AB. Drug prices in SwedenJuly 2000. Stockholm: Apoteket; 2000.

22. Brasil, Ministério da Economia, Fazenda e Planejamento. Portaria $n^{\circ} 37$. Diário Oficial da União. Brasília: Imprensa Nacional; 11 maio 1992.

23. Agência Nacional de Vigilância Sanitária (Anvisa). Regulação econômica do mercado farmacêutico [Internet site]. Available from: http://www.anvisa.gov.br/monitora/regula farmaceutico.pdf. Accessed 10 June 2001.

24. Abrahams N, Adhikari R, Bhagwat IP Christofides N, Djibuti M, Dyalchand A, et al. Changing the debate about health research for development. J Public Health Policy 2004; 25 (3-4):259-87.

Manuscript received on 30 June 2006. Revised version accepted for publication on 6 July 2007. 
RESUMEN Objetivo. Los precios constituyen un obstáculo clave para el acceso del consumidor a los medicamentos esenciales, especialmente en los países en desarrollo. El objetivo de este estudio fue comparar los precios minoristas de los medicamentos esenciales

Precios minoristas de medicamentos esenciales en Brasil: comparación internacional

Palabras clave en el mercado privado de Brasil con los de dos estándares internacionales de precios. Méthodos. Se compararon los precios minoristas de todos los medicamentos de la Lista de Medicamentos Esenciales de Brasil, edición de julio de 2000, con los precios minoristas de los mismos medicamentos en el mercado de Suecia y los indicadores de precios mayoristas de referencia de suministradores de bajo costo en el mercado internacional. Se calculó la razón entre los precios de cada medicamento en Brasil y en Suecia y entre los de Brasil y los precios mayoristas internacionales promedio por unidad. Se empleó el análisis de regresión lineal para estudiar también las razones según el número de productores.

Resultados. Los precios unitarios minoristas de los 132 medicamentos contenidos tanto en la lista de Brasil como en la de Suecia fueron 1,9 veces mayores en Brasil. De los 94 medicamentos que están tanto en la lista de Brasil como en el indicador internacional de precios unitarios, los precios unitarios nacionales promedio en Brasil fueron 13,1 mayores. No se encontró relación entre el número de productores de cada medicamento y la razón de precios.

Conclusiones. Los precios minoristas promedio de los medicamentos esenciales en Brasil son significativamente mayores que en Suecia. Además, según los precios mayoristas internacionales, las compañías farmacéuticas privadas de Brasil pudieran estar sacando al mercado medicamentos con precios excesivamente altos en relación con los costos de producción, lo que origina elevados márgenes de ganancia. No se encontró el efecto esperado de reducción de precios debido a la competencia.

Medicamentos esenciales, costos en drogas, economía farmacéutica, política de salud, Brasil.

\section{Taller Internacional sobre Tuberculosis}

Fechas: $\quad 26$ y 27 de noviembre de 2007

Lugar: Barcelona, España

En las fechas indicadas, la Unidad de Investigación en Tuberculosis de Barcelona, España, celebrará su undécimo taller, cuyas actividades gravitarán en torno al objetivo de mejorar la prevención y el control de la tuberculosis en España. Los principales temas serán los casos importados, la resistencia, el VIH y la transmisión.

Información:

Carmen Serrano

Tel: 93 238.45.55, Fax: 93-218 2275

e-mail: cserrano@aspb.es

http://www.aspb.es/uitb/D0CS2/triptic2007.pdf 